\title{
Nghiên cứu khí hậu cần những đóng góp toàn cầu
}

sciencevietnam

SSHPA (10-06-2021) - Mới đây, trang tin chuyên về các vấn đề biến đổi khí hậu Carbon Brief đã có bài điều tra chuyên sâu về sự đa dạng trong giới tính và vị trí địa lý của ngành nghiên cứu khí hậu [1].

Dựa trên danh sách 100 nghiên cứu được trích dẫn nhiều nhất trong 5 năm qua, tác giả Ayesha Tandon đã cho thấy lỗ hổng nghiêm trợng giữa các cộng đồng khoa học ở Bắc và Nam bán cầu. Dựa trên thống kê trích dẫn của Google Scholar, 100 bài nghiên cứu trong lĩnh vực khoa học khí hậu của hơn 1300 tác giả đã được lọc ra để phân tích. Trong đó, 73.9\% số tác giả có cơ quan làm việc tại Châu Âu hoặc Bắc Mỹ. Số tác giả từ Châu Â, Nam Mỹ, và Châu Phi chỉ chiếm 10.8\%, thậm chí số tác giả Châu Phi chỉ chiếm $0.7 \%$.

Nếu xét theo quốc tịch, phần đông tác giả đều tới từ Hoa Kỳ, Úc và Anh (lần lượt chiếm $30 \%, 15 \%$ và $10 \%)$. Khu vực Châu Á và Châu Phi vẫn là khu vực trắng khi rất nhiều quốc gia không có tác giả nào. Lục địa Châu Phi dù có tới hơn 50 quốc gia nhưng chỉ có 10 tác giả, với 8 người là từ Nam Phi.

Nếu xét tới tác giả dẫn dắt, không hề có tác giả dẫn dắt nào tới từ Châu Phi hay Nam Mỹ; còn Châu Á đóng góp vỏn vẹn 7 người (5 tới từ Trung Quốc).

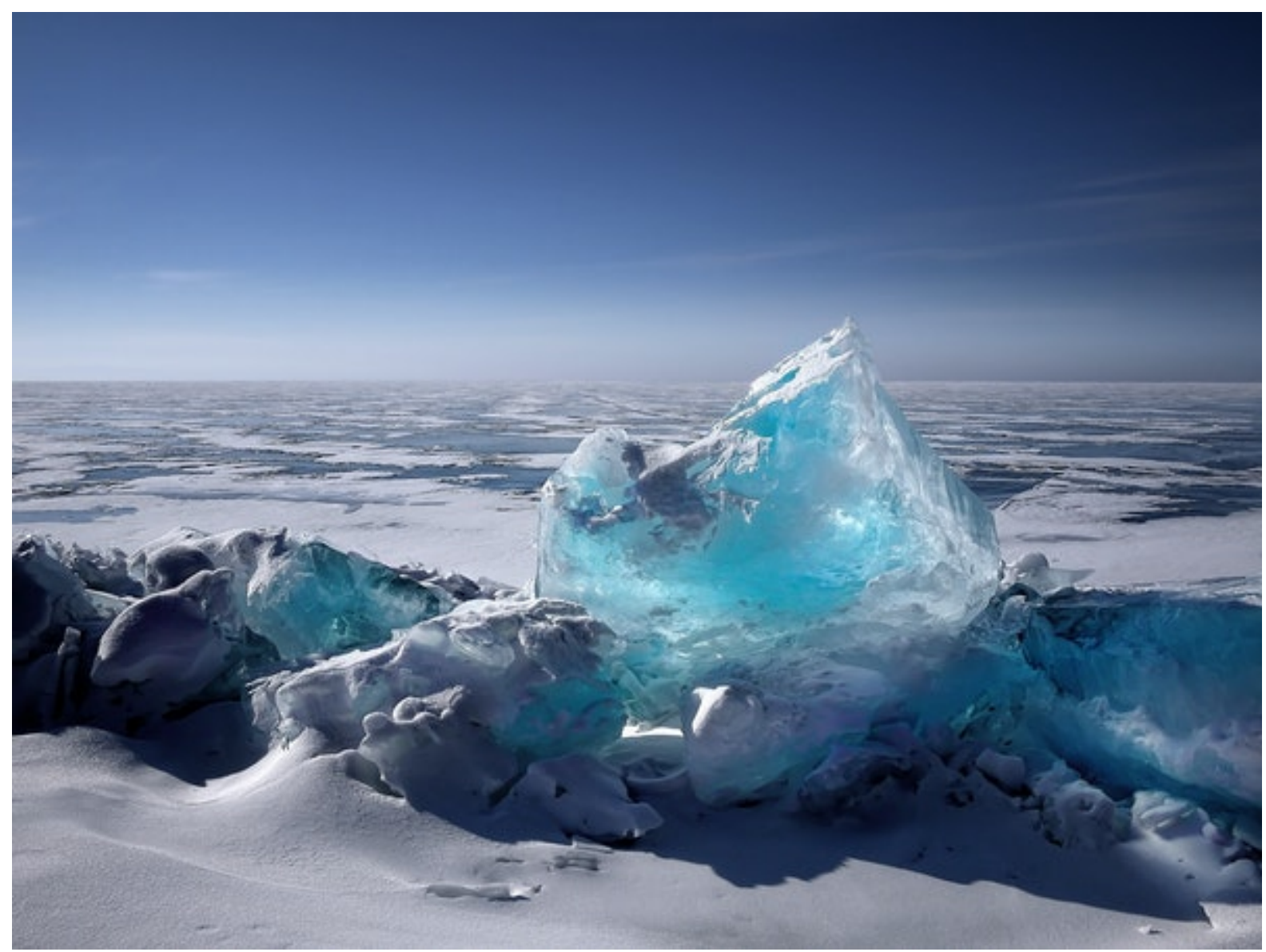


Bên cạnh khía cạnh địa lý, vấn đề bất bình đẳng giới cũng rất rõ ràng trong phân tích của Carbon Brief: Chỉ có $22 \%$ số tác giả là nữ giới. Tại các khu vực ở phía Bắc bán cầu, xu hướng này rất rõ ràng khi số tác giả nữ chiếm dưới 40\%: 20\% tại Châu Âu, 35\% tại Bắc Mỹ, và 29\% tại Châu Úc.

Để tìm hiểu rõ hơn về thực trạng nghiên cứu, tác giả Ayesha Tandon đã phỏng vấn nhiều chuyên gia từ các quốc gia khác nhau, trong đó có cả Việt Nam với chia sẻ của TS. Vương Quân Hoàng (Trung tâm Nghiên cứu Xã hội Liên ngành, Trường Đại học Phenikaa). Hâuu hết các tác giả tới từ Châu Á, Nam Mỹ, hay Châu Phi đều không quá bất ngờ với sự phân hóa rõ rệt về số lượng tác giả tới từ các khu vực này.

Câu chuyện kinh tế, ngôn ngữ, và sự hợp tác thiếu bình đẳng là các nguyên nhân cơ bản được Carbon Brief chỉ ra. Hiện tại, hầu hết các quốc gia Châu Á, Nam Mỹ, hay Châu Phi đều đầu tư rất ít vào khoa học, nên việc các nhà nghiên cứu không có đủ chi phí để làm việc diễn ra rất thường xuyên. Trong khi đó, lĩnh vực nghiên cứu khí hậu ngốn tài nguyên một cách khủng khiếp. Điều này dẫn tới việc các nhà nghiên cứu từ các quốc gia giàu có sẽ nhờ các nhà nghiên cứu tại các quốc gia ở Nam bán cầu thu thập dữ liệu, vì chi phí nhân công rẻ, và đây cũng là các khu vực chịu ảnh hưởng biến đổi khí hậu rõ rệt nhất.

Điều này dẫn tới mối quan hệ bất bình đằng, trong đó, các nhà khoa học Châu Á, Châu Phi hay Nam Mỹ chỉ được coi là người làm công; còn các nhà khoa học Mỹ, Anh hay Úc với tiềm lực mạnh mẽ hơn có nhiều quyền quyết định hơn. Carbon Brief gọi đây là khoa học thực dân.

Không chỉ bất bình đẳng trong nghiên cứu, quá trình công bố nghiên cứu cũng khiến các nhà khoa học Nam bán cầu gặp bất lợi rõ rệt vì ngôn ngữ, và xu hướng "publish or perish." Các vấn đề như chi phí xuất bản và truy cập bài báo cao, hay quá trình biên tập thiếu minh bạch, hay việc viết thật hay bằng tiếng Anh đều gây cản trở cho quá trình công bố.

Quá trình đầu tư vào khoa học, thay đổi các xu hướng xuất bản thiếu minh bạch, công bằng, mang tới tiếng nói cho phụ nữ là $[2,3,4]$ tiếp tục được đẩy mạnh. Đối mặt với thực tế bất bình đẳng này, cộng đồng khoa học đã và đang tiếp tục thay đồi để mang tới những đóng góp toàn cầu cho một vấn đề toàn cầu như khí hậu.

\section{Tài liệu tham khảo:}

[1] Tandon A. (2021). Analysis: The lack of diversity in climate-science research. Carbon Brief. URL: https://www.carbonbrief.org/analysis-the-lack-of-diversityin-climate-science-research

[2] Vuong QH. (2020). Reform retractions to make them more transparent. Nature, $582(7811), 149$.

[3] Vuong QH. (2019). Breaking barriers in publishing demands a proactive attitude. Nature Human Behaviour, 3(10), 1034.

[4] Vuong QH. (2018). The (ir)rational consideration of the cost of science in transition economies. Nature Human Behaviour, 2(1), 5.

Last modified: 10/6/2021 5:20 PM Views: 4 O 